\title{
Rural Entrepreneurship in India : Challenges and Opportunities
}

\author{
Dr. Pradeep Kumar Mishra
}

Assistant Professor, Faculty of Commerce and Management, Madhav University, Abu Road, Rajasthan, India

\begin{abstract}
Enterprise is the way toward planning, propelling and maintaining another business, for example a new business offering a item, procedure or administration. It has been characterized as the limit and readiness to create, sort out and deal with a business adventure alongside any of its dangers so as to make a benefit. Endeavour and business enterprise are the drivers of financial development in India's country regions. With the continuous difficulties confronting customary country divisions, the future accomplishment of the rustic economy is inseparably connected to the limit of provincial business visionaries to improve, and to recognize new business openings that make occupations and pay in country zones. A provincial business visionary is confronting numerous issues due to not accessibility of essential conveniences in rustic regions of creating nation like India. Absence of instruction, budgetary issues, inadequate specialized and calculated capacity it is excessively hard for the provincial business visionaries to set up enterprises in the rustic zones. This paper makes an endeavor to discover the Challenges and aptitudes for the probability of Rural Entrepreneurship and possibilities of the equivalent to be a fruitful business person.
\end{abstract}

Keywords : Rural Entrepreneurship, Agribusiness, Rural Individuals

\section{INTRODUCTION}

Provincial newly setup industries with innovative idea is characterized in more extensive sense "as the eager eagerness of a resident to sort out their financial matters action, whatever it might be (a business, an occupation, a speculation and so forth) with the assistance of suitable innovation and practices considered for a maintainable living."

Country business enterprise has a significant task to carry out in the advancement of Indian economy. Considering the way that almost 70 percent of the Indian populace calls country India it's home, sufficient subsidizing and backing can give a flourishing business visionary environment in these networks. So far as it is referred to that country India when contrasted with the standard populace is monetarily poor, more youthful, progressively detached geologically, secluded from the primary markets, socially imbedded in custom, less unique financially and encountering elimination.

It is to be seen that the greater part of the business person improvement approaches are custom fitted to address the issues of the urban India. Such approaches should be changed by setting up such focuses which only arrangement with the rustic networks and give counselling and examination offices. These focuses would then be able to give a system between the disconnected rustic India and overcome any issues between these urban and provincial networks. The vast majority of the organizations in provincial India are family possessed 
along these lines giving a firm enterprising base which can be misused by the foundation of the rustic business visionary focuses. As per an ongoing report by the Rural Policy, rustic territories who simply need backing to indicate their hunger for the government assistance of general society. These are the social business visionaries working in non-benefit ventures, for example, social equity association, smaller scale undertakings and business affiliation.

The most over looked part of the rustic India, that can be misused, is the procedure of eradication. A considerable lot of the youthful excited individuals turn towards the urban areas so as to satisfy their longing to get fruitful. Since, the provincial India can't give the development chance to these youthful business visionary to succeed, the greater part of them end up in securing conventional and the board positions. Remembering the assets that a capable world nation has and the sort of rustic assets that nations like India support, if the legislature can give an impetus to these youngsters to remain in their networks and help them in setting up business visionary tasks from their own family claimed organizations, such a program can realize an unequalled achievement in provincial networks.

Objectives of the study The following are the objectives of the present study:

1. To know the various types of rural entrepreneurship.

2. To analyse the performance of rural industries.

3. To know the importance of rural entrepreneurship.

4. To study the problems of rural entrepreneurship.

\section{METHODOLOGY}

The present study is based only on secondary data. The data were collected from books, journals, website and annual reports.

\section{Need for Rural Entrepreneurship:-}

After more than six many years of freedom and industrialization in our nation, still huge piece of populace stays under destitution line. Agribusiness keeps on being the foundation of country society. According to this examination, $70 \%$ of possessions are held by little and minimal ranchers bringing about congestion on the horticultural land and decreasing homestead produce. This additionally brings about relocation of homestead specialist in enormous numbers to the urban territories. In both the cases the populace stays under neediness line. Rural work power has a portion of $70 \%$ in the all out work power of the nation. Cultivators who own farmland come to around sixty-eight percent of this work power while horticultural work represents the staying thirty two percent. These cultivators are expanding in numbers throughout the years yet the huge increment was among the farming work, which went up from $20 \%$ of the country work power to thirty two percent. One additionally needs to remember that there is a nonstop development of populace. In this way, the approach for rustic enterprise advancement needs to handle, the issues by giving other occupation choice to the provincial young people. "Young people in the country regions have little alternatives", this is the thing that they are given to accept. This is the explanation that a large number of them either work at cultivate or relocate to urban land. The need is to plant other alternative in the psyches of rustic youth. Business enterprise could be the most ideal alternative. Whenever planted and supported in the psyches of rustic ladies and youth, It could result is reforming the Indian economy. It ought to be underscored that the ventures attempted by these business people ought not be obliged by its area in provincial regions. It ought to appreciate all the benefits of the area. So what is surprising about a resident essentially sorting out their financial aspects action? In this specific circumstance, it is exceptional that most of this crucial workforce, since it is chaotic, abandons standardized savings, work preparing, advertise 
information, protection, medicinal services, simple access to credit, proficient procedures for creation, promoting, bookkeeping and so forth... The rundown is unending. While the administration and an enormous number of NGOs are attempting to address the different needs of the disorderly part, any commitment, anyway little it is, made by anybody is a much needed refresher for the individuals in this segment. Enhancement into non-agrarian employments of accessible assets, for example, providing food for sightseers, blacksmithing, carpentry, turning, and hand creates and toys and so on. Just as broadening into exercises other than those exclusively identified with farming use, for instance, the utilization of assets other than land, for example, water, forests, structures, accessible abilities and neighbourhood includes, all fit into country business enterprise. The pioneering mixes of these assets are, for instance: the travel industry, game and amusement offices, expert and specialized preparing, retailing and wholesaling, modern application (building, makes), overhauling (consultancy), esteem included (items from meat, milk, wood and so on,) and the chance of off-ranch work. Similarly enterprising are new employments of land that empower a decrease in the force of agrarian creation , for instance, natural creation, dynamic rustic business visionaries can likewise be found. They are growing their exercises and markets and they find new markets for their items and administrations past the neighbourhood limits.

\section{Opportunities for Rural Entrepreneurship:}

Bolster \&Motivation to nearby individuals: Rural business visionaries have a great deal of help from the Rural individuals. Rustic town individuals consistently energize and give the inspiration to the business visionaries.

Low foundation cost: When contrasted with the urban regions, rustic business people's business foundation cost is low. There is no compelling reason to develop or offices enormous foundation and structures.

Upper hands/Availability of work: In India $70 \%$ of the individuals are living in the town. Greater parts of the provincial individuals are relying upon the farming. The farming work isn't accessible consistently. That is the motivation behind why rustic business visionaries have the upper hand in effectively obtaining incompetent and semiskilled work.

Government approaches and appropriations: The administration of India is persistently checking and presenting the new strategies for empowering the country business enterprise. These approaches are truly adaptable, creative, changed and giving proceeds with help to country business visionaries. Simultaneously government has likewise reported enormous appropriations for promoting the provincial business.

Accessibility of crude materials. The majority of the occasions the country business visionaries are relying on the ranch based items as crude materials, which are accessible consistently. These crude materials are accessible in the rustic zone that is the explanation there is no transportation cost and buoyancy cost.

Cost of creation: Rural business visionaries cost of creation is extremely low when contrasted with the urban industries. The variables of creation are accessible with minimal effort; naturally the expense of creation is additionally low. Because of these rustic business visionaries can sell their merchandise and enterprises with less expensive expense.

Ideal utilization of produces: Optimum utilization of homestead produces is just conceivable through the rustic enterprise only. Most of the country business visionaries rely on the ranch produces as crude materials.

Work age for youth: Rural business visionaries are giving hundred percent occupations to provincial youth. On the off chance that the provincial business visionaries are prevailing in this action the movement 
of the individuals to urban from rustic will be promptly halted to a greatest degree.

Advancement cost: There is no advancement cost for rustic business visionaries; in actuality the opposition is less. Especially there is no requirement for publicizing and other limited time exercises for their items.

Expected client: In this twenty-first century provincial residents are monetarily solid and furthermore vigorously populated. This overwhelming populace can be changed over as potential customers. That is the explanation all the MNC's are gathered in provincial towns for their probability.

Building the generosity: Rural business people have a great deal of degree constructing the altruism. The vast majority of the rustic business visionaries have moral qualities and furthermore these individuals don't work for unadulterated benefits.

\section{Challenges of Rural Entrepreneurship}

Rustic business enterprise has its own downsides. Approaches, for example, keeping of land in insurance when there is an over creation and valuing pay are two of the best strings to provincial business. Because of the remote access and inaccessibility of learned work, business markets and administrative staff are ruined because of the remote areas. So as to ease the issues of rustic business enterprise, under the administration upheld assets for these undertakings and select just the absolute best thoughts that legitimately advantage the network as well as can contend on a worldwide scale. It is additionally fundamental for the achievement of the rustic networks that the improvement of each provincial undertaking stay in the hand of the neighbourhood organizations which consequently help out the legislature to manage the main factor that can help build up the country regions.

Appropriation and Coordination: Infrastructure contains to be a test in provincial India. Additionally, the absence of an effective conveyance arrange forestalls entrance of items/administrations into provincial India.

Instalment assortment: most of the country populace is still unbanked. Obviously, non-money assortment turns out to be somewhat improbable. Money assortment, then again, are muddled and hard to screen.

Estimating: it is simpler to gather in bigger sums as each case of assortment and conveying of money has related expense. Discretionary cash flow, through , isn't in every case high since the heft of provincial India is horticulture and pay cycle in agrarian are whimsical and not as unsurprising as on account of us salaried people.

Scaling across geologies: India is a place where there is numerous societies and convention, the difference become that a lot starker on account of rustic India. Setting up procedure on a dish India level present various sorts of obstacles in various states running from poltical shuffling to out and out neighborhood factors. Any model where versatility includes scaling on-ground tasks will undoubtedly run into heap issues as we move starting with one state then onto the next. Add to that the more prominent contrasts in customer tastes and conduct across geographies then in the moderately progressively cosmopolitan urban populace.

Creating inorganic scale: Developing manufactured scale through organizations commonly brings about bigger overheads in the provincial setting. Finding the correct cooperate with reach and nearness in towns in hard to begin with. All the more critically, there are not many players who are solid on these checks over numerous normally requires associations bringing about higher accomplice the board overheads.

Social and social difficulties: The digital bistro model has not worked in numerous pieces of rustic India due to socio-social issues. One reason for the disappointment of the stand model in Kuppam (HP's I-people group) was the absence of utilization by 
ladies which was generally because of their uneasiness in going to booths run by men.

Development of Mall culture: Because of the globalization and present day economy empowering the shopping centres culture as opposed to the customary shops. Another side provincial Indian individuals pay is additionally expanded, in light of that these individuals likewise pulled in to shopping centre culture.

\section{Helpless Assistance and Power disappointment:} These two are the significant difficulties looked by the rustic individuals. India is certainly not a created nation, it is as yet creating nation. Also India, don't have an adequate force and power framework offices to fulfil the necessities of their kin. For filling the hole between the interest and inaccessibility the legislature of India have been resolved to control sliced to provincial zones.

Absence of specialized ability: Rural Indian individuals they don't have solid specialized instructive information. That is the explanation these individuals don't have the foggiest idea how to utilize most recent innovation. Still dominant part of the provincial business people customary and old innovation.

Lack of knowledge There is a distinct lack of adequate knowledge of entrepreneurial opportunities among the rural youth. The educated and trained youths mostly leave for urban destinations in search of jobs.

Foundation ailment: The country India despite everything enduring with need framework offices. Be that as it may, a similar time government likewise not concentrates for making the country framework. This is the pitiful circumstance of rustic India. Helpless mental self portrait of rustic youth and lacking inspiration: Strong inspiration is the mahamantra for accomplishment of any action. Especially the rustic youth are enduring with helpless mental self portrait. This is slaughtering the gifts of the country youth.

Lack of technical knowledge: On relation of the faulty education system rural youth lack managerial, professional, technical knowledge which is an impediment in developing the spirit of enterprise, consequently not many people come forward to establish self-employment units.

Social qualities: We can observe one thing here; in contrasting with the urban individuals the country individuals have been focused on solid social qualities. In this globalizes world the most conventional individuals are likewise fatly embracing the outside societies and customs. Truth be told the provincial individuals don't simple to change the social qualities.

\section{Conclusion}

In spite of the fact that agribusiness today despite everything gives pay to provincial networks, country improvement is progressively preferred to big business advancement. Since national economies are increasingly more globalize and rivalry is escalating at a phenomenal pace, influencing industry as well as any financial movement including agribusiness, it isn't astounding that rustic business enterprise is picking up in its significance as a power of monetary change that must occur if numerous provincial networks are to survive. In any case, business enterprise requests an empowering situation so as to prosper. It is very evident that rustic business enterprise can't be created without critical preparing. Thusly, rather than just plans (money related and advancement) as the right for business enterprise improvement a concentrated preparing should be given to the adolescent in country India. What's required is to make a gave group to take up country enterprise preparing according to coordinated rustic advancement program. To oversee farming segment and non-enclave ventures in country territories, provincial business visionaries need to apply altogether unique administration and regulatory ideas. Else we will be just making island of obvious success in the expanse of country destitution. Rustic business enterprise is the response to expulsion of country 
neediness in India. Consequently, there ought to be more weight on coordinated country advancement.

\section{REFERENCES}

[1]. Annual Reports, Ministry of Micro, Small and Medium Enterprises, Government of India.

[2]. Brijesh Patel and Kirit Chavda, "Rural Entrepreneurship in India: Challenges and Problems", International Journal of Advanced Research in Computer Science and Management Studies, 12, pp.28-37, 2013.

[3]. D. Joel Jebadurai, "An Overview of Problems of Rural Entrepreneurs in India", International Journal of Advanced Research in Management and Social Sciences, 27, pp. 202-208, 2013.

[4]. Dipanjan Chakraborty, "Socio-Economic Determinants of Growth of Rural Entrepreneurship in Sonitpur District of Assam-An Empirical Study", Journal of Behavioural Economics, Finance, Entrepreneurship, Accounting and Transport, 21, pp. 26-34, 2014.

[5]. H. Bhuvaneswari and S. Raju, "A Study on Rural Entrepreneurship with Sivaganga District", Global Journal for Research Analysis, 33, pp. 5-7, 2014.

[6]. http://epao.net/epSubPageExtractor.asp?src=ed ucation.J

obs_Career.The_need_for_rural_entrepreneurs hip_By_N_Joyson_Tao

[7]. Essays, UK. November 2018. Opportunities And Challenges For Rural Entrepreneurship In India Economics Essay. Retrieved from https://www.ukessays.com/essays/economics/o pportunities-and-challenges-for-ruralentrepreneurship-in-india-economicsessay.php?vref=1

[8]. https://en.wikipedia.org/wiki/Climate_of_India Author: WikiMedia, MediaWiki,

[9]. http://www.publishyourarticles.net/eng/article s2/what-are-the-problems-faced-in-growth-of- rural-entrepreneurs-in-india/2723/ Author: Sameer, Pub: publishyourarticles, Year: 2015

[10]. https://www.researchgate.net/publication/ Author: Kirk Heriot, Neol Campbell, Pub: ResarchGate, Year: 2005

[11]. https://www.scribd.com/doc/26661470/RuralEntrepreneurship-in-India\#scribdAuthor: Kirk Heriot, Neol Campbell, Pub: Scdibd, Year: 2010

[12]. http://nextbillion.net/thinkimpact-offers-anew-approach/ Author: Saul Garlic, Pub: NextBillion, Year: 2010

\section{Cite this Article}

Dr. Pradeep Kumar Mishra, "Rural Entrepreneurship in India : Challenges and Opportunities", International Journal of Scientific Research in Science and Technology (IJSRST), Online ISSN : 2395-602X, Print ISSN : 2395-6011, Volume 4 Issue 11, pp. 673-678, November-December 2018. Available Journal URL : https://ijsrst.com/IJSRST18401197 